\title{
Representasi Perempuan dalam Tulisan dan Gambar Bak Belakang Truk: Analisis Wacana Kritis Multimodal Terhadap Bahasa Seksis
}

\author{
Eggy Fajar Andalas dan Arti Prihatini \\ Pendidikan Bahasa dan Sastra Indonesia, Universitas Muhammadiyah Malang \\ eggy@umm.ac.id \\ artiprihatini@umm.ac.id
}

\begin{abstract}
Abstrak
Fenomena budaya kontemporer berisi kebebasan berkekspresi, bahkan gambar dan tulisan di belakang bak truk menjadi media ekspresi representasi terhadap perempuan. Penelitian ini bertujuan untuk melihat bagaimana representasi perempuan dalam gambar dan tulisan bak truk. Pendekatan yang digunakan adalah pendekatan kualitatif dengan metode deskriptif. Data berupa gambar dan tulisan di belakang bak truk yang merepresentasikan perempuan yang bersumber dari laman google.co.id. Analisis data dilakukan dengan pemaknaan terhadap bahasa dan gambar hingga tahap denotasi dan konotasinya. Hasil penelitian menunjukkan bahwa perempuan lebih banyak direpresentasikan dalam hal uang, cinta, dan seks secara negatif. Dalam hal uang dan cinta, perempuan direpresentasikan mengambil keuntungan dari laki-laki dari uang dan cinta yang diberikannya. Dalam hal seks, perempuan dapat berposisi sebagai pihak yang aktif sekaligus sebagai pihak yang pasif. Bahasa seksis langsung (overt sexism language) berupa pameo, kalimat imperatif, frasa nomina, sarkasme, serta kata dalam bahasa Indonesia atau bahasa Jawa yang lafalnya ditulis dalam bahasa Inggris. Bahasa seksis tak langsung (covert sexism language) berupa presuposisi, implikatur, repetisi, dan diksi konotatif. Bahasa yang digunakan adalah bahasa Indonesia dan bahasa Jawa.
\end{abstract}

Kata kunci: representasi perempuan, analisis wacana kritis multimodal, bahasa seksis

\section{Abstract}

Contemporary cultural phenomena contain freedom of expression, even the images and writing behind the truck become a medium for expression of representation towards women. This study aims to see how the representation of women in the images and writing of a truck. The approach of this research is a qualitative approach 
with descriptive methods. Data of this research are images and writing behind a truck representing women which originate from the google.co.id page. Data analysis were done by interpreting the writing and images to the denotation and connotation stages. The results showed that women were more represented in terms of money, love, and sex negatively. In terms of money and love, women are represented taking advantage of men from the money and love they give. In the case of sex, women can act as active parties as well as passive parties. Overt sexism languages were represented by slogans, imperative sentences, noun phrases, sarcasm, and Indonesian or Javanese words whose pronunciation is written in English. Covert sexism languages were represented by presuppositions, implicatures, repetitions, and connotative diction. The languages used in the writing behind the truck are Indonesian and Javanese.

Keywords: women representation, multimodal critical discourse analysis, sexism language

\section{PENDAHULUAN}

Munculnya beragam fenomena budaya kontemporer yang identik dengan perwujudan kebebasan berkekspresi oleh segala lapisan masyarakat. Beragam media digunakan sebagai alat untuk merefleksikan ide, pandangan, atau kepentingan melalui komunikasi visual karena di dalamnya dapat diwakilkan tanda yang menyimpan pesanpesan tertentu, seperti film, iklan, foto, majalah, dan bahkan gambar di belakang bak truk. Sebagaimana dikemukakan Vahid dan Esmae'li (2012:41) bahwa gambar terdiri atas tandatanda yang dapat direpresentasikan dan tanda tersebut disusun dalam hubungan tertentu untuk menghasilkan struktur gambar tersebut. Ademilokun dan Olateju (2015:2) juga menjelaskan bahwa komunikasi dalam dunia modern saat ini membentuk dimensi baru yang mengabaikan ekspresi verbal saja, tetapi mengedepankan komunikasi multimodal yang melibatkan media lain, seperti gambar.

Berkaitan denganhal itu, realitas permasalahan mengenai posisi perempuan dalam budaya telah terrefleksikan dalam bentuk film, novel, cerpen, iklan, berita, folklor. Salah satunya adalah informasi dan representasi terhadap perempuan yang dianggap subordinat oleh laki-laki yang tampak pada gambar dan tulisan di belakang bak truk. Berkaitan dengan hal itu, Kennedy (Juwita, 2009:15) memaparkan bahwa terdapat empat dimensi dalam gambar, yaitu sebagai konvensi, refleksi serupa yang bertindak sebagai wakil, mengungkapkan elemen-elemen yang sama dari suatu objek atau peristiwa yang diwakili, dan mengungkapkan informasi yang sama dari objek atau peristiwa yang diwakilinya. Selain itu, Vahid dan Esmae'li (2012:39) juga menjelaskan bahwa gambar dan bahasa merupakan dua hal yang berbeda, tetapi bentuk, wujud, pengaruh, dan bahkan struktur budayanya sama. Jika digabungkan, gambar dan bahasa tersebut menyimpan pesan multimodal.

Tidak hanya pandangan, media komunikasi visual juga digunakan sebagai alat penyebaran ideologi kekuasaan. Hal itu tampak pada penelitian terdahuluyang dilakukan oleh Mondong (2011) berjudul Representasi 
Perempuan dalam Iklan Pond's. Iklan menampilkan hiperrealitas. Perempuan ideal digambarkan berkulit putih dan bercahaya, seksi, serta menarik perhatian lawan jenis. Iklan tersebut tidak hanya memberikan kesan kepuasan laki-laki, tetapi juga memberikan kepuasan tersendiri bagi perempuan yang merasa dirinya presentable, acceptable, dihargai, dan dibutuhkan oleh laki-laki, padahal secara implisit perempuan telah direpresentasikan secara pasif dan materialistik. Aripurnami (Astuti, 2004) melakukan penelitian pada film Indonesia akhir 1980-an. Perempuan ditampilkan lebih mandiri, tetapi masih "takut" untu mandiri secara penuh. Ruang gerak perempuan digambarkan sebatas lingkungan domestiknya dan dari kelas menengah yang persoalan-persoalannya disederhanakan tentang cinta segitiga saja.

Berdasarkan pembahasan tersebut, terdapat permasalahan mengenai representasi perempuan dalam bentuk komunikasi visual (gambar). Perempuan menjadi objek bagi lakilaki sehingga kedudukan perempuan dianggap tidak lebih tinggi dibandingkan laki-laki.

Bahasa yang demikian disebut dengan bahasa seksis. Hal itu sesuai dengan pendapat Cameron (2006: 16) bahwa bahasa seksis tidak hanya berupa kata dan frasa, tetapi kata dan frasa tersebut berisi pandangan dan keyakinan bahwa perempuan lebih inferior dibandingkan dengan laki-laki. Sebagaimana dikemukakan Darwesh dan Abdullah (2016:87) sebagai berikut.

Bahasa bukanlah alat yang netral dalam merepresentasikan realitas. Bahasa dapat dideskripsikan sebagai alat yang digunakan untuk mendiskriminasi, menghina, menyalahgunakan, dan mengecilkan orang lain. Kondisi tersebut merupakan contoh kasus bahasa seksis yang menggunakan bahasa sebagai alat untuk mendiskriminasi perem- puan dengan merepresentasikan perempuan secara negatifatau secara implisit menganggap aktivitas yang berkaitan dengan perempuan adalah hal yang sepele.

Pada gambar belakang truk, bahasa seksis banyak ditemukan. Tanda dalam gambar dan kata-kata yang digunakan merupakan ideologi para supir truk dalam merepresentasikan wanita. Johnston (Christandi, 2013:3) berpendapat sebagai berikut.

perempuan "dituliskan" melalui pemben-
tukan stereotip dan mitos bahwa ia adalah
suatu tanda yang dipertukarkan; begitulah
akhirnya perempuan berfungsi dalam bentuk-
bentuk budaya dominan, karena itu dalam
bidang seni dan juga dalam teks film, repre-
sentasi perempuan terutama bukanlah suatu
tema atau persoalan sosiologis, seperti sering
dipikirkan, melainkan sebuah tanda yang
sedang dikomunikasikan.

Berkaitan dengan halitu, untuk mengungkap makna dalam wacana berbentuk kata-kata dan gambar, diperlukan teoriyang mampu menjangkau keduanya agar terkuak pesan di dalamnya secara lebih mendalam. Sebagaimana dikemukakan Knox, Patpong, dan Piriyasilpa (2010:103) bahwa analisis linguistik dan multimodal serta teori pengembangan lainnya dibutuhkan dan perlu ditambahkan dengan pendekatan empiris dan pendekatan dasar semiotik yang melengkapi pendekatan yang digunakan pada praktik sosial dan pengaruh media tersebut. Pada konteks ini, digunakan analisis wacana kritis (AWK) multimodal dan analisis bahasa seksis. Fairclough (2016:105) menjelaskan AWK bersifat transdisipliner sehingga perlu dipadukan dengan teori lain, seperti teori yang berkaitan dengan sosial. Jancsary, Hollerer, dan Meyer (2016:180) serta Connolly dan Phillips (2002:169) juga mengungkapkan bahwa teks multimodal tidak hanya menyimpan pesan dalam kata-kata, tetapi juga menyimpan tanda di luar bahasa, seperti gambar yang juga perlu dianalisis. 
Penelitian ini juga menggunakan teori analisis wacana kritis pada bahasa seksis Sara Mills untuk menelaah representasiperempuan dari sisi kebahasaannya. Mills (2008:1-22) menyebutkan bahasa seksis terdiri atas beragam penggambaran perempuan, yaitu (1) evaluasi negatif, (2) sebagai pengikut dan tergantung pada laki-laki, (3) lemah dan tidak berkompeten, (4) sebagai objek tak bernyawa, (5) sebagai barang kepemilikan, (6) dinilai dari penampilannya saja, (7) korban perlakuan tidak pantas dan penganiayaan, (8) berbahasa vulgar dengan perempuan, dan (9) presentasi negatif terhadap perempuan.

Mills (2008: 11-12) menyebutkan dua jenis bahasa seksis, yaitu bahasa seksis yang bersifat langsung (overt sexism) dan tak langsung (covert sexism). Mills (2008:65-85) menyebutkan karakteristik bahasa seksis yang bersifat langsung, yaitu (1) kata ganti generik, yang maknanya dipahami secara universal untuk laki-laki dan makna untuk perempuan adalah tersendiri, (2) kata benda generik yang makna umumnya untuk laki-laki padahal sebenarnya untuk laki-laki maupun perempuan, seperti siswa dan muda, (3) imbuhan yang mengakhiri kata (sufiks) sebagai penanda gender, seperti -wan pada santriwan (laki-laki) dan-wati pada santriwati (perempuan), (4) kata sapaan untuk perempuan berbeda untuk yang sudah/belum menikah, seperti nona dan mbak untuk yang belummenikah dan nyonya dan bu untu yang sudah menikah, tetapi hal itu tidak berlaku pada laki-laki, (5) kata hinaan seperti perempuan tuna susila dan mucikari (6) pasangan kata yang memiliki hubungan gender, seperti suami-istri dan priawanita, (7) pepatah, peribahasa atau pameo. Sementara itu, bahasa seksis yang tak langsung dapat berupa humor atau presuposisi yang cenderung lebih implisit dalam menampilkan ideologinya. Berdasarkan hal itu, penelitian ini penting dilakukan untuk mendeskripsikan bagaimana perempuan digambarkan oleh supir truk melalui kata-kata dan gambar sebagai bentuk pandangannya terhadap kedudukan dan peran perempuan dalam masyarakat.

\section{METODE}

Pendekatan penelitian ini adalah kualitatif dengan metode deskriptif. Penelitian ini termasuk dalam penelitian kualitatifkarena sesuai dengan pendapat Moleong (2014:6) dan Bogdan dan Guba (dalam Suharsaputra, 2012:181), bahwa penelitian kualitatif adalah penelitian yang bermaksud memahami fenomena yang dialami oleh subyek penelitian, misalnya perilaku, persepsi, motivasi, tindakan dan lain-lain secara holistik, dan dengan cara deskripsi dalam bentuk katakata dan bahasa, pada suatu konteks khusus yang alamiah dengan memanfaatkan berbagai metode ilmiah. Metode deskriptif adalah metode yang dilakukan dengan jalan mengalisis data yang sudah dikumpulkan berupa kata-kata, gambar, dan bukan angka-angka (Moleong, 2014:11). Alasan peneliti menggunakan metode ini sesuai dengan pendapat Lofland, yang menyebutkan sumber data utama dalam penelitian kualitatif ialah kata-kata dan tindakan, selebihnya adalah tambahan seperti dokumen dan lain-lain (Moleong, 2014:157).

Jenis penelitian ini adalah penelitian kepustakaan yang dilakukan dengan penelusuran pustaka terutama dimaksudkan tidak hanya sebagai kerangka penelitian saja, tetapi riset pustaka sekaligus memanfaatkan sumber perpustakaan untuk memperoleh data penelitian (Zed, 2008:1-2). Tujuannya adalah untuk menemukan pola katakata dan gambar yang merepresentasikan perempuan di belakang bak truk. Sebagaimana dikemukakan Mautner (2016:157) bahwa analisis wacana dipahami sebagai aktivitas sistematis 
untuk mendeskripsikan pola dalam teks yang dihubungkan dengan pola konteks di masyarakat.

Sumber data penelitian ini adalah internet. Data mengenai tulisan dan gambar belakang bak truk diperoleh dari laman www.google.co.id/. Gambar dipilih berdasarkan empat kriteria, yaitu 1) tidak buram, 2) objek wanita, 3) asli bukan hasil suntingan, dan 4) di belakang bak truk. Pengumpulan data dilakukan dengan teknik dokumentasi. Analisis data dilakukan dengan mendeskripsikan dan menginterpretasi gambar dan tulisan pada tulisan dan gambar bak belakang truk.

\section{HASIL}

Hasil penelitianmenunjukkan bahwa bahasa seksis yang ditemukan terdiri atas delapan wujud penggambaran perempuan, yaitu (1) evaluasi negatif, (2) sebagai pengikut dan tergantung pada laki-laki, (3) lemah dan tidak berkompeten, (4) sebagai objek tak bernyawa, (5) sebagai barang kepemilikan, (6) dinilai daripenampilannya saja, (7) korban perlakuan tidak pantas dan penganiayaan, (8) berbahasa vulgar dengan perempuan, dan (9) presentasi negatif terhadap perempuan. Pada sembilan tipe itu, perempuan diasosiasikan dalam tiga hal secara negatif, yaitu uang, seks, dan cinta. Dalam hal uang dan cinta, perempuan tampak mengambil keuntungan dari laki-laki dari uang dan cinta yang didapatkannya. Dalam hal seks, perempuan dapat berposisi sebagai pihak yang berinisiasi sekaligus sebagai pihak yang menerima hasrat seks dari laki-laki.

Data gambar dianalisis berdasarkan penggunaan garis, warna, dan ekspresi wajah pada objek gambar. Berdasarkan hal itu, temuan menunjukkan bahwa garis yang digunakan berwujud horizontal, vertikal, dan melengkung dengan ketebalan garis yang bervariasi. Warna yang digunakan ada yang sederhana dan lembut dan ada pula yang kombinasi dan kompleks.
Penggunaan garis dan warna tersebut disesuaikan dengan isi tulisan yang ada pada belakang bak truk. Pada umumnya, ekspresi wajah perempuan yang ditampakkan adalah dengan tatapan mata menggoda serta berpakaian minim dan ketat. Hal itu menunjukkan representasi perempuan yang menunjukkan bagian tubuhnya dan cenderung mementingkan penampilan.

Berdasarkan jenis bahasa seksis Mills, ditemukan data yang tergolong bahasa seksis langsung (overt) dan tak langsung (covert). Bahasa seksis langsung (overt) terwujud dalam penggunaan kata hinaan dan pameo. Selain karakteristik bahasa seksis Mills, ditemukan bahasa seksis langsung (overt) yang berbentuk kalimat imperatif, frasa nomina, sarkasme, serta kata dalam bahasa Indonesia atau bahasa Jawa yang ditulis dalam bahasa Inggris. Di sisi lain, bahasa seksis tak langsung (covert) berwujud presuposisi. Di luar karakteristik bahasa seksis Mills, ditemukan juga implikatur, repetisi, dan diksi konotatif pada tipe bahasa seksis tak langsung.

\section{PEMBAHASAN}

Pada pembahasan ini, diuraikan mengenai dua hal, yaitu (1) wujud representasi perempuan, dan(2) tipe bahasa seksis representasi perempuan dalam tulisan dan gambar bak belakang yang dijelaskan sebagai berikut.

\section{WUJUD REPRESENTASI PEREMPUAN DALAM TULISAN DAN GAMBAR BAK BELAKANG TRUK}

Berdasarkan data yang ditemukan, hampir 90\% bagian belakang truk menjadikan wanita sebagai objek gambar. Laki-laki menjadi subjek dengan kekuatannya, sedangkan perempuan sebagai objek yang lemah. Perempuan-perempuan dijadikan objek ekploitasi seksual laki-laki yang terbingkai dalam bentuk wacana media. Hal tersebut merupakan permasalahan gender. Fakih 
(1996:12) memaparkan permasalahan mengenai gender tidaklah menjadi permasalahan selama tidak melahirkan ketidakadilan. Persoalan muncul karena perbedaan gender telah melahirkan berbagai ketidakadilan, walaupun laki-laki tidak menutup kemungkinan akan menjadi korban ketidakadilan gender, tetapi perempuan masih tetap menduduki posisi tertinggi sebagai korban ketidakadilan gender. Ketidakadilan gender itu terwujud dalam penggunaan yang bersifat seksis. Bahkan, Swim \& Hyers (2009: 407) menyebutkan bahwa bahasa seksis merupakan praktik sikap, keyakinan, dan perilaku individual, organisasional, institusional, dan kultural yang merefleksikan penilaian negatifberdasarkan gender atau mendukung ketidaksamaan status antara laki-laki dan perempuan.

Permasalahan mengenai bagaimana posisi perempuan dan bagaimana perempuan dikonstruksikan oleh laki-laki tidaklah bisa dilepaskan dari budaya patriarki yang selama ini hidup dalam kebudayaan masyarakat di berbagai belahan dunia. Hal itu sesuai dengan pendapat Ponterotto (2014:107) bahwa kecenderungan representasi perempuan digambarkan sebagai objek dan cenderung tidak dilihat kompetensi profesionalnya yang merupakan dampak pemikiran patriarki terhadap representasi pe rempuan tidak lebih tinggi dari laki-laki. Berkaitan dengan hal di atas, Kurnia (2004:17-18) mengatakan media adalah arena perebutan posisi, yaitu posisi “memandang' dan posisi yang "dipandang". Hal yang diperebutkan adalah 'tanda' yang mencerminkan citra tertentu. Pada gambar belakang bak truk, laki-laki menduduki posisi 'memandang', sedangkan perempuan sebagai yang 'dipandang'. Karena 'dipandang', perempuan bukanlah subjek, tetapi sebagai objek yang dikenai tindakan oleh laki-laki.

Gambar tersebut merupakan ungkapan ideologi patriarki supir-supir truk yang seorang laki-laki terhadap pandangannya terhadap perempuan. Perempuan digambarkan sebagai objek pemuas hasrat laki-laki, sehingga posisi perempuan menjadi objek yang lemah dan tertindas. Pandangan tersebut tidaklah lepas dari pandangan mengenai maskulinitas dan feminitas yang terdapat pada laki-laki dan perempuan. Karakter maskulin laki-laki digambarkan dengan sifat kuat, keras, dan beraroma keringat, sedangkan perempuan dengan sifat lemah, lembut, dan beraroma wangi dan diidentikkan dengan seorang putri. Di sisi lain, mitos mengenai perempuan sebagai pelayan laki-laki yang hanya bertindak dalam domain domestik saja (rumah tangga), yang hanya terkait dengan permasalahan mangan, macak, masak, manak masih tertanam hingga saat ini. Wacana mengenai bagaimana perempuan direpresentasikan dalam berbagai bentuk media sebagai pihak yang tertindas atas dominasi laki-laki menjadi wacana yang belum berubah. Perempuan telah menjadi penanda pesan yang dikomunikasikan dalam budaya patriarki.

Berikut ini adalah beberapa data yang ditemukan yang dianalisis berdasarkan penggunaan garis, warna, dan ekspresi wajah serta gambar latar belakangnya (background). 


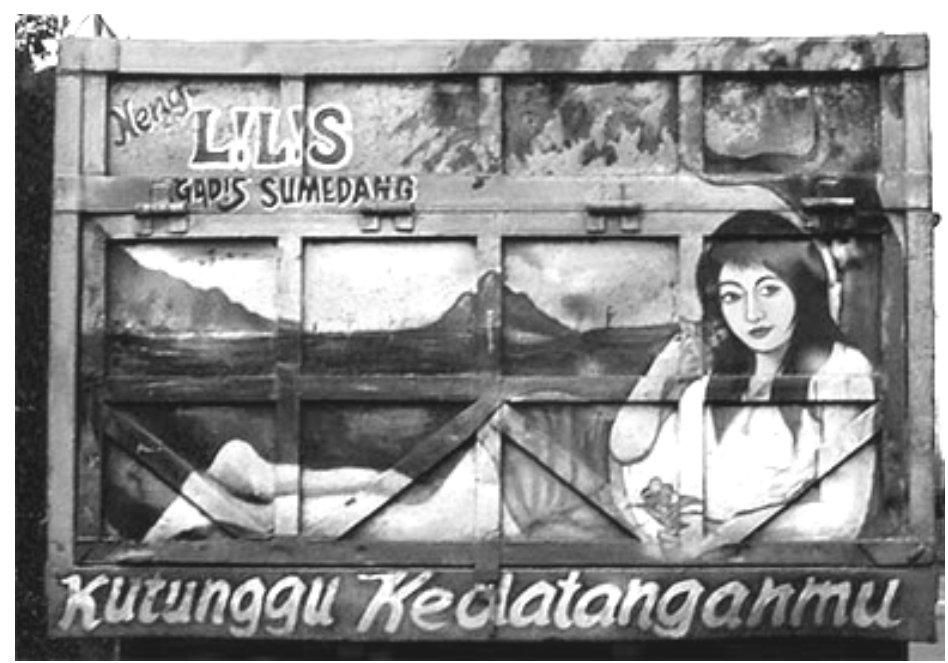

Gambar 1. Sosok Wanita yang Menantikan Kedatangan Seseorang

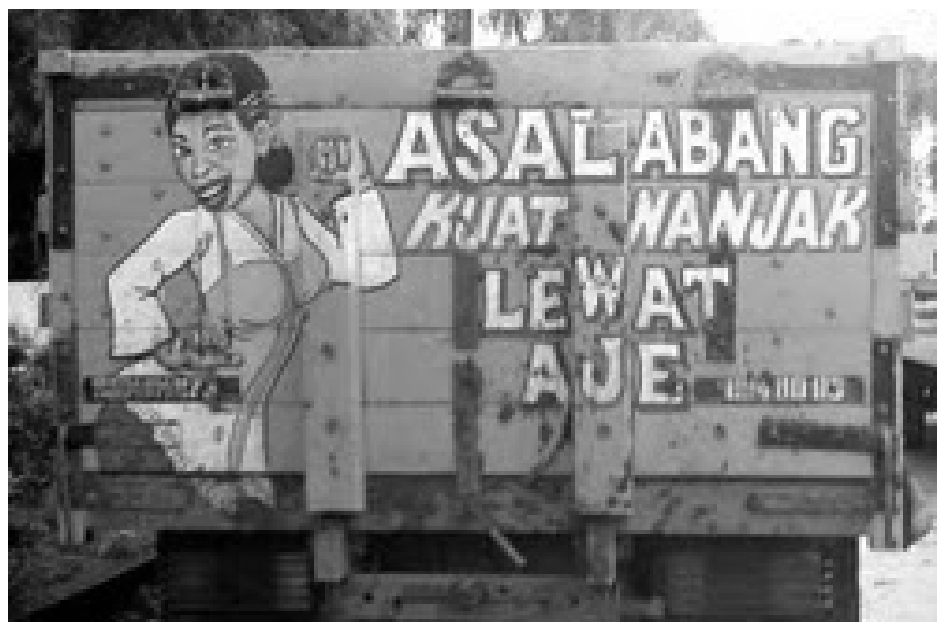

Gambar 2. Seorang Perempuan yang Menantang Laki-Laki

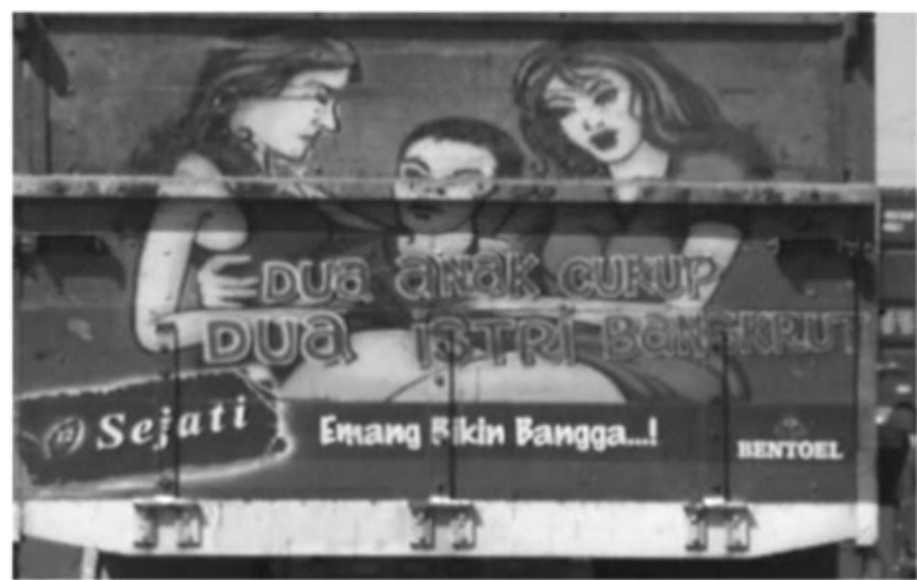

Gambar 3. Gambaran Pria Beristri Dua 


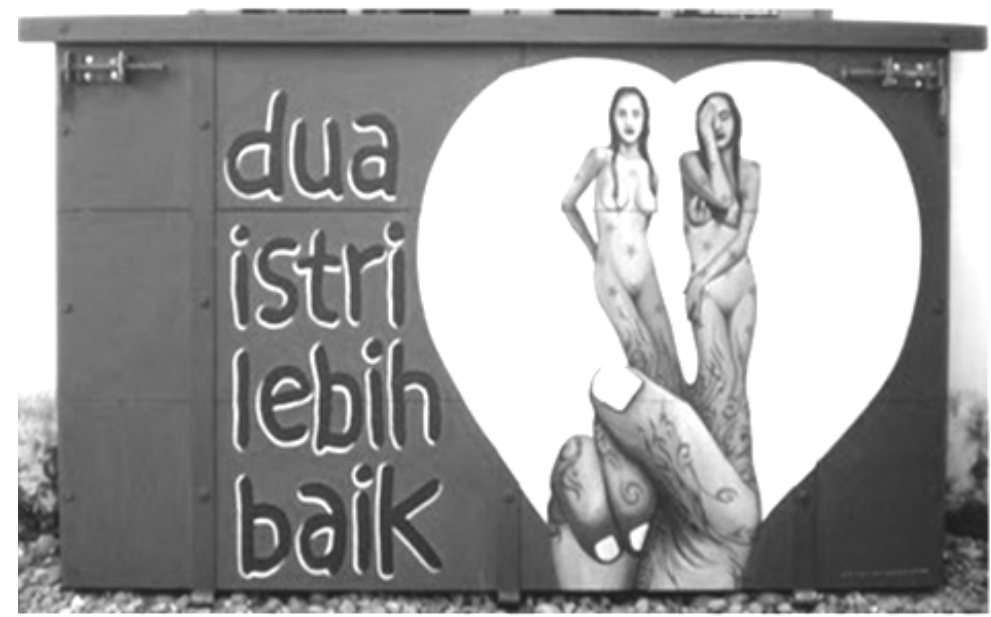

Gambar 4. Gambaran Beristri Dua

Pada gambar 1 , terlihat perempuan dengan posisi yang menantang, santai, sensual, memakai pakaian seksi, dan senyum menggoda memberikan pesan kepada penonton yang memandangnya mengenai suatu hal. Terdapat sejumlah petanda yang terdapat dalam gambar tersebut. Tubuh perempuan yang sedang tidur menyamping menghadap ke depan membentuk bidang yang hampir memuat sebagian besar gambar.Pakaian seksi dengan balutan rok mini dan baju minimalis menandakan hasrat menggoda kepada orang yang melihatnya. Senyumnya memperlihatkan ikatan phatik yang dibangun untuk terlibat di dalamnya. Latar gambar pegunungan, pohon rindang, dan dua buah gunung berjajar yang berwarna biru mengisyaratkan adanya keteduhan. Dengan petunjuk etnisitas sebagai gadis Sunda yang geulis dan dipertegas dengan tulisan kutunggu kedatanganmu mengisyaratkan hasrat wanita yang ingin terpenuhi oleh laki-laki.

Garis-garis yang digunakan dalam gambar tersebut cenderung tipis dan melengkung yang memberikan efek kelembutan seorang perempuan. Sebagaimana dikemukakan Tian (2010:138) bahwa garis yang tipis dan melengkung merepresentasikan kelembutan atau kepasrahan. Hal itu juga didukung dengan posisi tubuh perem- puan yang menyamping secara horizontal yang menunjukkan ekspresi kelembutan dan kepasrahan. Hal itu juga dijelaskan oleh Adams (2008:134) bahwa garis horizontal menunjukkan ekspresi berbaring. Jadi, perempuan direpresentasikan pasrah dengan berbaring untuk memberikan kode bagi laki-laki untuk memenuhi hasratnya.

Gambar 2 juga memperlihatkan hal yang sama seperti gambar 1. Gambar 2 memperlihatkan sosok perempuan dengan pose yang sensual, yaitu bagian tubuh condong ke depan dan tangan bertolokan pinggang seperti posisi menantang. Sosok perempuan digambarkan dengan bermulut lebar dengan lipstik yang tebal berwarna merah. Pakain tertutup rapat, akan tetapi terdapat pakaian dalam yang digunakan sebagai pelapis pakain luar berwarna pink yang menonjolkan bentuk tubuhperempuantersebut. Dibagian depangambar terdapat tulisan yang menjadi sentral isi pesan yaitu asal abang kuat nanjak lewat aje.

Pada gambar 2, terlihat juga sejumlah penanda yang sentral yang teramati yaitu posisi tubuh perempuan yangmengisyaratkan posisimenantang. Tulisan kalau abang kuat lewat aje yang mengisyaratkan sebuah tantangan terhadap kejantanan laki-laki terhadap perempuan. Balutan busana perempuan yang menonjolkan bentuk bagian 
dada mengisyaratkan mengenai kemolekan tubuh wanita. Posisi tubuh perempuan tersebut menonjolkan anggota tubuhnya bagian depan (payudara) dan belakang (pantat) sedangkan kepalanya ditarik ke belakang sehingga jika ditarik garis, tubuh perempuan membentuk garis zigzag dari kepala, payudara, pantat, dan kaki. Adams (2008:13-4) menjelaskan bahwa garis zigzag menunjukkan sisi agresif dan tegas. Pada gambar tersebut, perempuan direpresentasikan sebagai sosok yang agresifdan tegas menyerukan tantangan seksual kepada laki-laki.

Pada gambar 3, tampak dua perempuan dengan pakaian terbuka sedang duduk mendekat mengapit satu laki-laki. Garis-garis yang digunakan pada gambar tersebut tebal dan tegas yang merepresentasikan perempuan yang tampak terbuka dan lugas dalam hal seks. Bahkan, gambar 4 tampak vulgar menunjukkan seluruh tubuh perempuan dengan pose yang sensual. Pada gambar 3 dan 4, dua perempuan diposisikan sejajar di samping kanan dan kiri sehingga jika ditarik garis, posisi tubuh perempuan itu tampak seperti dua garis vertikal. Adams (2008:13-4) mengemukakan bahwa dua garis horizontal mengeksperesikan keseimbangan, keharmonisan, dan pergerakan yang berkelanjutan. Berdasarkan hal itu, jika ditinjau dari tulisan Dua anak cukup, dua istri bangkrut dan dua istri lebih baik, representasi yang tampak adalah laki-laki yang memiliki dua istri tetap dapat berlaku adil/ seimbang sehingga tetap harmonis sehingga poligami tersebut tetap dapat berlanjut. Secara implisit, perempuan direpresentasikan sebagai pihak yang lemah karena kewenangan untuk berpoligami ada pada laki-laki, tetapi perempuan tetap menjalani poligami tersebut karena alasan tertentu.

Warna dominan gambar 3 dan 4 pun merah sehingga menambah citra agresif dan menggoda yang melekat pada diri perempuan. Sebagaimana dikemukakan Kress dan van Leeuwen (1996 dalam Tian, 2010:142) bahwa makna dalam gambar dapat dilihat dari teknik pewarnaannya yang mencakup kepekatan, kecerahan, dankecemerlangan gambar. Berdasarkan hal itu, gambar 1-4 menggunakan teknik pewarnaan yang cerah, pekat dan cukup cemerlang sehingga gambar tersebut merepresentasikan perempuan secara jelas, lugas, dan terbuka bahwa perempuan adalah objek seks laki-laki.

Selain keempat gambar itu, juga ditemukan gambar lain di belakang bak truk yang menggunakan teknik pewarnaan dengan banyak kombinasi warna yang cerah, pekat, dan cemerlang. Gambar yang demikian merepresentasikan kondisi yang rumit dankompleks. Hal itu sesuaidengan pendapat Tian (2010:143) bahwa kombinasi aneka warna pada gambar menunjukkan adanya kekacauan. Jadi, representasi laki-laki terhadap perempuan cenderung rumit, kacau, dan kompleks yang menyangkut banyak hal.

Selain agresif dan menggoda, perempuan direpresentasikan sebagai sosok yang bergantung pada laki-laki dalam hal finansial. Akan tetapi, sosok laki-laki digambarkan sebagai pihak yang harus mencari uang untuk perempuan. Bahkan, kemurnian dan ketulusan cinta perempuan dipertanyakan karena bergantung pada banyaknya uang yang diterimanya, seperti pada data yang berbunyi Cinta bersemi saat dompetku terisi, Senyumanmu merobek dompetku, dan Senyumanmu menambah bon-ku. Perempuan direpresentasikan sebagai sosok yang tidak mandiri dan mengandalkan laki-laki untuk mencukupi kebutuhannya. Cinta perempuan dicap tidak tulus dan dilabeli sebagai sosok yang 'materialistis'.

Selain representasinegatif, ditemukan representasi positif terhadap perempuan, tetapi 
jumlahnya tak sebanyak representasi negatif. Representasi positif berisi doa, harapan, dan ungkapan perasaan darisopir terhadap perempuan yang dikasihi, yaitu ibu, istri, atau kekasih seperti data berikut.

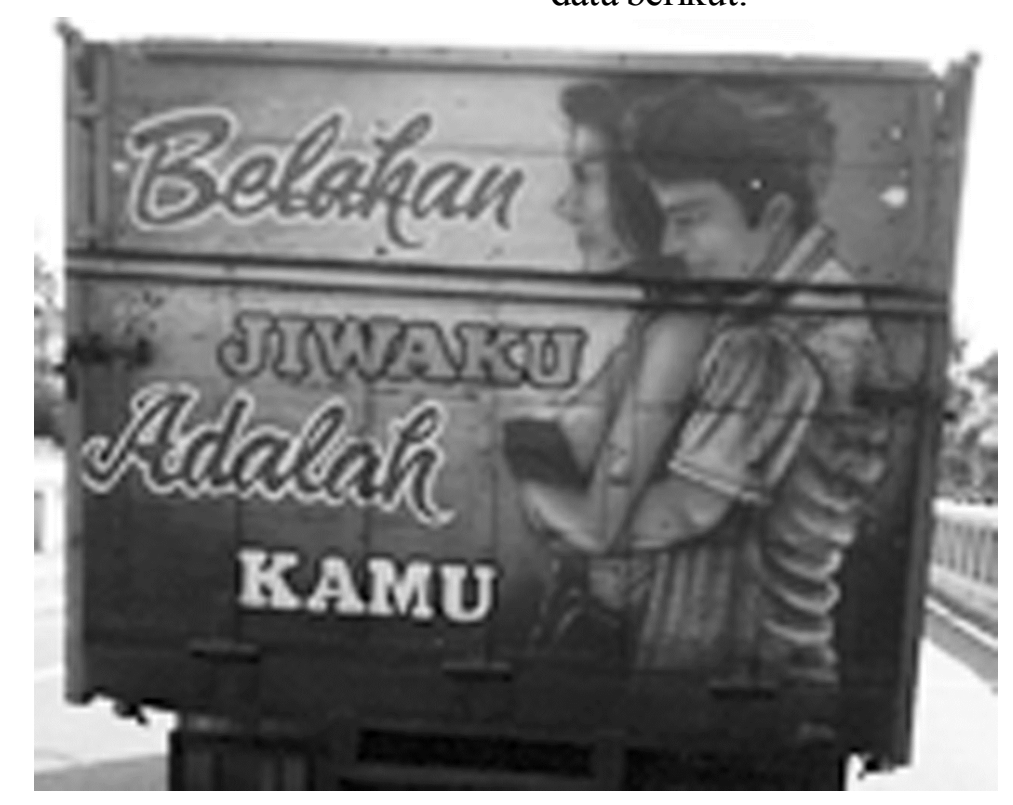

Gambar 5. Ungkapan Perasaan Sopir

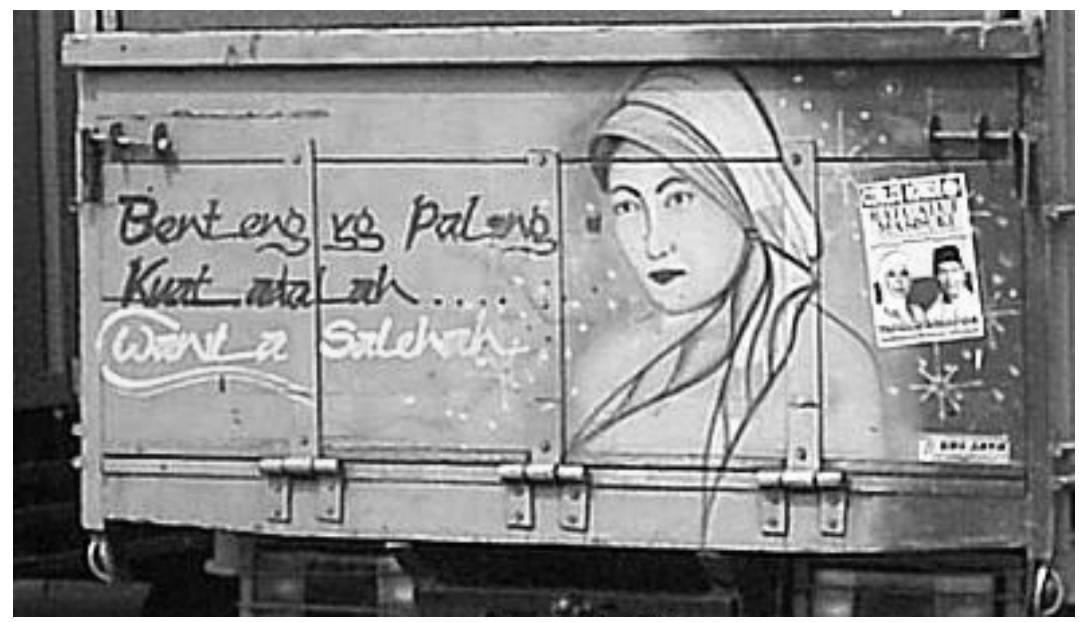

Gambar 6. Ungkapan Perasaan Sopir

KARAKTERISTIK BAHASA SEKSIS kata dalam bahasa Indonesia atau bahasa Jawa DALAM REPRESENTASI PEREMPUAN yang lafalnya ditulis dalam bahasa Inggris. Di sisi PADA TULISAN DAN GAMBAR BAK lain, bahasa seksis tak langsung (covert) berwujud BELAKANG TRUK

Berdasarkan dua tipe bahasa seksis Mills, data yang ditemukan adalah bahasa seksis langsung (overt sexism) dan bahasa seksis tak langsung (covert sexism). Bahasa seksis langsung (overt) terwujud dalam penggunaan pameo. Selain karakteristik bahasa seksis Mills, ditemukan bahasa seksis langsung (overt) yang berbentuk kalimat imperatif, frasa nomina, sarkasme, serta presuposisi. Di luar karakteristik bahasa seksis Mills, ditemukan juga repetisi, implikatur, dan diksi konotatif pada tipe bahasa seksis tak langsung. Pada umumnya, bahasa yang digunakan pada tulisan belakang truk adalah bahasa Indonesia dan bahasa Jawa. Selain itu, bahasa yang digunakan banyak menggunakan rima, yakni persamaan bunyi pada akhir frasa/klausa yang pertama dan kedua. 


\section{BAHASA SEKSIS LANGSUNG (OVERT SEXISM)}

Bahasa seksis langsung ini dijelaskan berdasarkan variasi temuannya sebagai berikut.

1. Pameo

Pameo merupakan sejenis peribahasa yang dijadikan semboyan(Hakim, 1995:vi dalam
Ponulele dkk, 1998:18). Pameo dapat berfungsi sebagai kalimat penyemangat atau sindiran. Berdasarkan data yang ditemukan, pameo pada belakang bak truk bertujuan memberikan semangat dan menyindir yang disajikan pada tabel berikut.

\section{Tabel 1. Temuan Pameo}

\begin{tabular}{|l|l|}
\hline \multicolumn{1}{|c|}{ Pameo Pemberi Semangat } & \multicolumn{1}{c|}{ Pameo Sindiran } \\
\hline - Menanti kejujuran, harapkan kepastian. & - Cinta bersemi saat dompetku berisi \\
- Belahan jiwaku adalah kamu. & - Senyumanmu merobek dompetku. \\
- Benteng yang paling kuat adalah wanita & - Senyummu menambah bonku \\
salehah. & - Cinta sopir hanya sebatas parkir. \\
- Pergi karena tugas, pulang karena cinta. & - Dibuang sayang, dimadu perang. \\
\hline
\end{tabular}

Pada tabel tersebut, pameo pemberi semangat merepresentasikan perempuan secara positif, sedangkan pameo sindirian merepresentasikan perempuan dan laki-laki secara negatif.

2. Kalimat Imperatif

Kalimat imperatifmerupakan bentuk kalimat yang bertujuan mengajak, menyuruh, atau melarang. Menurut Sneddon dkk (2010:333) bahwa struktur modus imperatif ditujukan kepada seseorang dengan tujuan bahwa sesuatu harus dilakukan, seperti perintah kuat untuk meminta, memohon, dan menyarankan. Berdasarkan data yang ditemukan, kalimat imperatifdigunakan untuk mengajak (menggoda) laki-laki untuk melakukan hal yang mengarah pada aspek seksual. Hal itu tampak pada data yang berbunyi Sini dong, Mas yang disertai gambar perempuan tidur menyamping, mata menggoda, dan memakai baju minim dan ketat berwarna merah serta data Gue aja kali yang dilengkapi gambar perempuan tengkurap, berpakaian minim, kaki terangkat, dan wajah menghadap ke depan dengan tatapan mata agresif. Pada data tersebut, representasi perempuan adalah agresif dan berinisiatif untuk mengajak/ menggoda laki-laki dengan penampilan fisiknya saja.

3. Frasa Nomina

Frasa nomina merupakan sekelompok kata yang mengacu benda konkret atau hal abstrak. Berdasarkan data yang ditemuan, satu frasa nomina digunakan dalam bak belakang truk dengan atau tidak disertai gambar. Data yang ditemukan adalah (1) sebatas gaya disertai gambar perempuan yang menggunakan baju yang minim bergaya sensual, (2) rayuan si jablai disertai gambar perempuan duduk menghadap samping dengan tatapan menggoda dan mengangkat salah satu kakinya, serta (3) pemburu janda tanpa disertai gambar. Data (1) dan(2) merepresentasikan secara lugas bahwa perempuan adalah sosok yang mementingkan penampilan saja dan agresif. Data (3) merepresentasikan janda dicari oleh laki-laki dengan alasan yang berkembang di masyarakat bahwajanda memilikipengalaman lebih dalam hal seksualitas. 
4. Sarkasme

Sarkasme merupakan jenis majas sindiran yang berisi hinaan dan cemoohan. Becker, Zawadzki, dan Shileds (2014:605) menyatakan bahwa diskriminasi terhadap perempuan dapat dilakukan dengan sarkasme. Temuan menunjukkan bahwa sarkasme digunakan untuk merepresentasikan perempuan secara negatif tentang ketulusan hati, cinta, dan perbandingan antara fisik dengan hati yang tampak pada data yang berbunyi (1) Busuk sampah tak sebusuk hatimu, (2) Pergi dicari, pulang dimarahi. Cintamu tak seberat muatanku, (3) Cintamu tak semurni solarku, serta (4) Ayune kaya ratu, atine kaya asu. Data (1) - (4) menunjukkan perempuan yang mendapatkan hinaan/ cemoohan dengan cara membandingkannya dengan sampah, muatan, solar, dan asu (anjing). Secara implisit, perempuan dilabeli sebagai orang yang hati dan cintanya tidaklah tulus.

5. Kata dalam Bahasa Indonesia dan Bahasa Jawa yang Lafalnya Ditulis dalam Bahasa Inggris

Temuan jenis ini tampak pada data berikut.

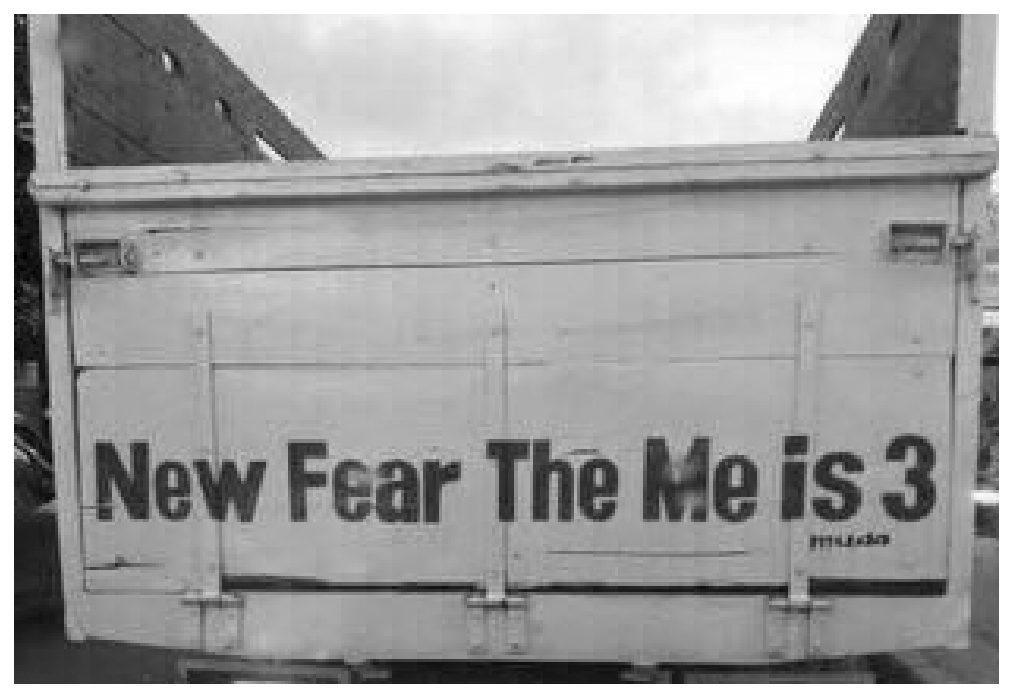

Gambar 7. Tulisan Nyupir demi Istri

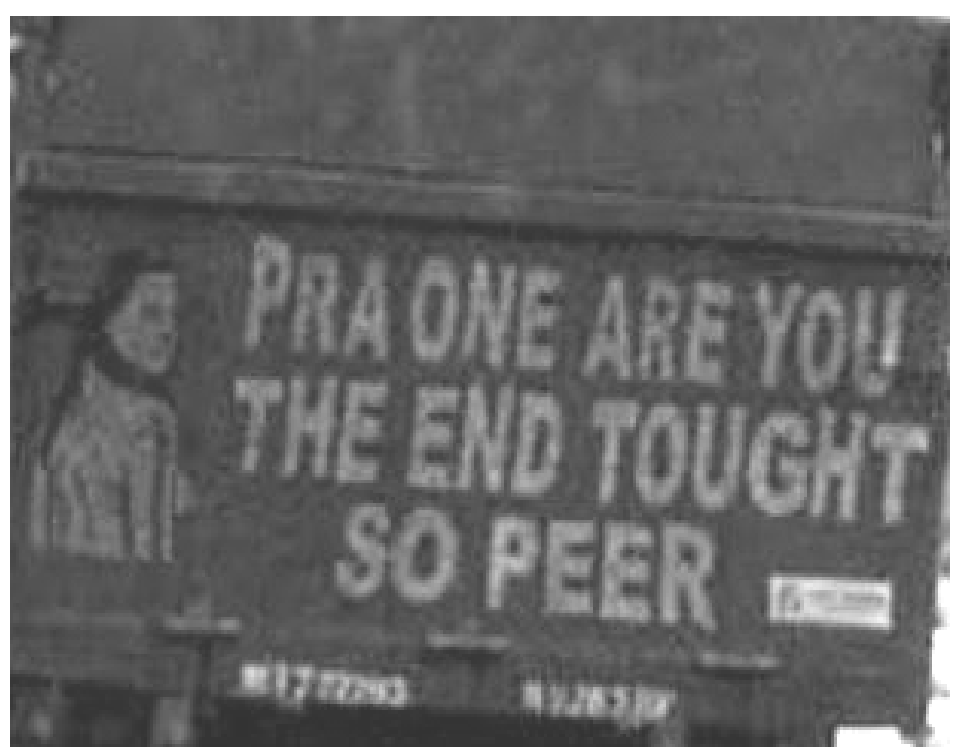

Gambar 8. Tulisan Prawan Ayu Dientot Supir 
Pada gambar 7, new fear the me is 3 bukanlah bahasa Inggris, tetapi bahasa Indonesia karena kalimat tersebut tidak memenuhi kaidah bahasa Inggris dan pelafalannya mewakili kalimat nyupir (newfear), demi (the me), istri (is 3). Gambar 8 juga demikian, yakni pelafalannya adalah prawan (pra one), ayu (are you), dientot (the end thought), supir (so peer). Kata dientot pada gambar 8 bermakna bersetubuh atau bersenggama. Karakteristik bahasa seksis jenis ini tergolong unik dan tidak banyak ditemukan. Pelafalan dalam bahasa Inggris membuat orang yang membaca berpikir dua kali untuk memahaminya. Jika mampu memahaminya, barulah orang yang memahami maksud tulisan tersebut. Pada gambar 7, representasi terhadap perempuan bersifat positif karena berisi ungkapan perasaan laki-laki yang bekerja untuk istri, sedangkan gambar 8 berisi representasi negatif karena berisi kata-kata vulgar yang mengarah pada posisi perempuan sebagai objek seksual laki-laki.

\section{BAHASA SEKSIS TAK LANGSUNG (COVERT SEXISM)}

Bahasa seksis tak langsung ini dijelaskan berdasarkan variasi temuannya sebagai berikut.

1. Presuposisi

Presuposisi merupakan suatu praanggapan yang dapat diketahui melalui konteks yang melingkupi suatu ujaran. Peccei (2000:19) menyatakan bahwa presuposisi adalah tuturan yang mengandung kesimpulan tentang sesuatu yang diasumsikan benar dengan berdasarkan seperangkat kondisi yang kuat agar tuturan tersebut sesuai dengan ketepatan keadaan yang digambarkan. Presuposisitampak pada tabel berikut.

Tabel 2. Temuan Presuposisi

\begin{tabular}{|l|l|l|}
\hline \multicolumn{1}{|c|}{ Data } & \multicolumn{1}{|c|}{ Deskripsi Gambar } & \multicolumn{1}{c|}{ Presuposisi } \\
\hline $\begin{array}{l}\text { Biar ompong } \\
\text { tapi nyedot. }\end{array}$ & $\begin{array}{l}\text { Laki-laki tua berdiri di } \\
\text { samping perempuan } \\
\text { yang kancing bajunya } \\
\text { terbuka sehingga } \\
\text { dadanya tampak. }\end{array}$ & $\begin{array}{l}\text { Laki-laki memiliki hasrat seksual yang kuat, } \\
\text { bahkan sampai ia tua dan ompong. Maka, laki- } \\
\text { laki tua akan tetap melakukan aktivitas seksual- } \\
\text { nya sebagaimana tampak pada kata nyedot. }\end{array}$ \\
\hline $\begin{array}{l}2 \text { anak cukup, } \\
\text { istri bangkrut. } \\
\text { Selingkuh ok. }\end{array}$ & Tanpa gambar & $\begin{array}{l}\text { Dua anak cukup merupakan jargon KB. Dua istri } \\
\text { bangkru bermakna bahwa kebutuhan } \\
\text { mencukupi dua istri dapat menghabiskan banyak } \\
\text { uang sampai seorang suami bangkrut. Sebagai } \\
\text { jalan pintasnya, suami tetap menjalin hubungan } \\
\text { dengan wanita lain secara ilegal (selingkuh). }\end{array}$ \\
\hline $\begin{array}{l}\text { Selingkuh boleh } \\
\text { saja asal rasa } \\
\text { sayang sama } \\
\text { istri jangan } \\
\text { sampai hilang. }\end{array}$ & Tanpa gambar & $\begin{array}{l}\text { Hal yang paling diinginkan dari perempuan } \\
\text { adalah rasa sayang dari suami. Jika suami } \\
\text { selingkuh, dianggap rasa sayang tersebut telah } \\
\text { hilang. Maka, suami berdalih bahwa akan tetap } \\
\text { sayang istri meskipun selingkuh. }\end{array}$ \\
\hline
\end{tabular}

Berdasarkan data dan analisis presuposisi tersebut, presuposisi/praanggapan yang berkembang di masyarakat adalah laki-laki memiliki hasrat seksual yang kuat dan memiliki peluang untuk berselingkuh, sedangkan perempuan adalah pihak yang pasif, dirugikan, dan terlukai perasaannya. Hal itu berkaitan dengan isu poligami, yakni laki-laki diperkenankan menikahi lebih dari satu perempuan jika mampu secara finansial dan dapat berlaku adil. Mampu dan adil sulit dilakukan sehingga keinginan untuk menjalin asmara 
dengan lebih dari satu perempuan diwujudkan dalam perselingkuhan. Pada konteks ini, perempuan menjadi pihak yang lemah dan korban tindakan menyeleweng laki-laki.

2. Repetisi

Repetisi merupakan pengulangan kata/frasa yang pada umumnya bertujuan untuk memberikan penegasan. Data repetisi yang ditemukan berbunyi aku janji ga akan nakal lagi, kalo aku nakal lagi, aku janji lagi. Kata yang mengalami repetisi adalah $a k u$, janji, dan nakal lagi. Tulisan tersebut berlatar belakang gambar seorang perempuan setengah badan yang mengenakan pakaian minim dan ketat dengan warna dominan merah. Berdasarkan hal itu, kata aku mengacu pada perempuan yang penampilannya mengumbar bagian tubuhnya, kata janji lagi pada akhir kalimat menunjukkan bahwa perempuan pernah berjanji sebelumnya, tetapi tidak ditepati, sedangkan kata nakal lagi bermakna bahwa perempuan tersebut telah bersikap 'nakal' sebelumnya dan berpotensi untuk melakukannya lagi di masa mendatang. Kata 'nakal' dapat dimaknai sebagai tindakan perempuan yang dilakukan dengan orang lain selain orang (laki-laki) yang sedang menjalin hubungan dengannya (pacar/suami). Secara implisit, kata 'nakal' mengarah pada perselingkuhan. Hal itu sesuai dengan pendapat Aitchison (1994:19-20) bahwa repetisi digunakan sebagai intensifikasi, yakni sejenis penambahan atau penguatan dalam hal kuantitas atau kualitas dan memiliki fungsi eksresif. Intensifikasi digunakan untuk menjelaskan bahwa perempuan secara tegas masih direpresentasikan secara negatif bahwa perempuan dapat berselingkuh lagi meskipun telah berjanji tidak akan mengulanginya lagi.

3. Implikatur

Implikatur merupakan tuturan yang secara implisit memiliki maksud tertentu. Beberapa data dan implikaturnya disajikan pada tabel berikut.

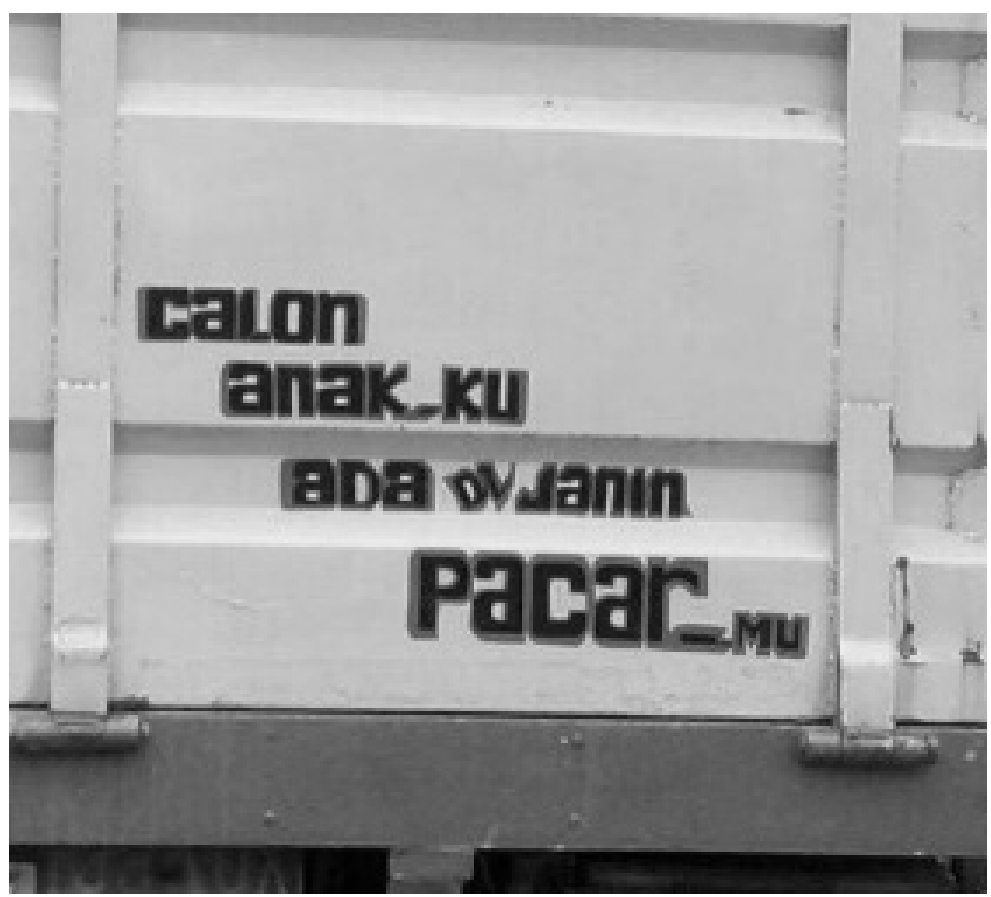

Gambar 9. Calon anakku ada di janin pacar-mu 


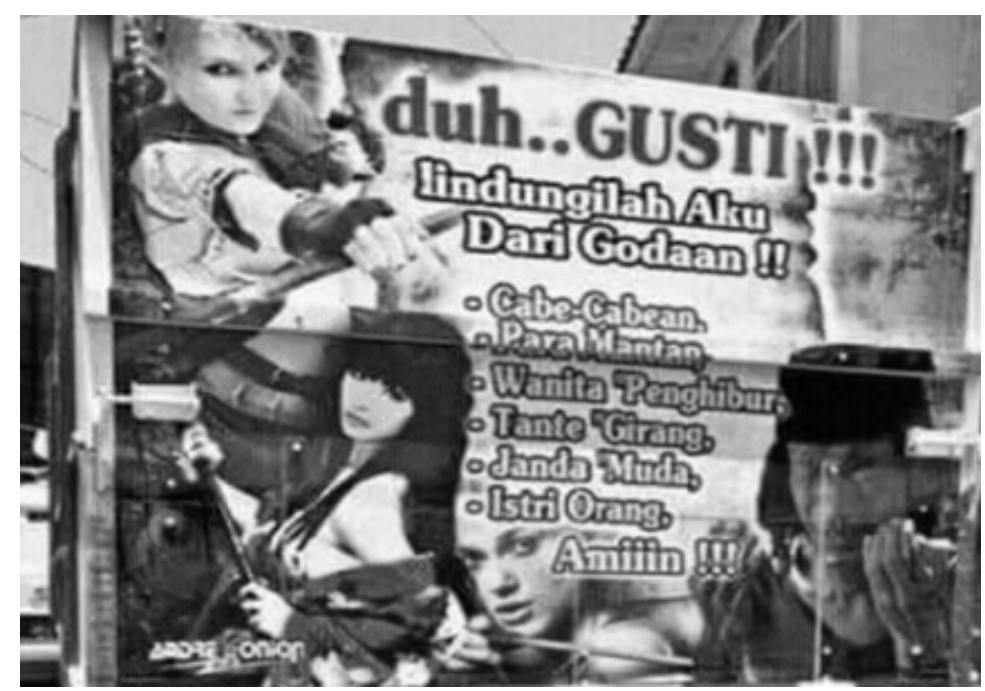

Gambar 10. Doa Supir

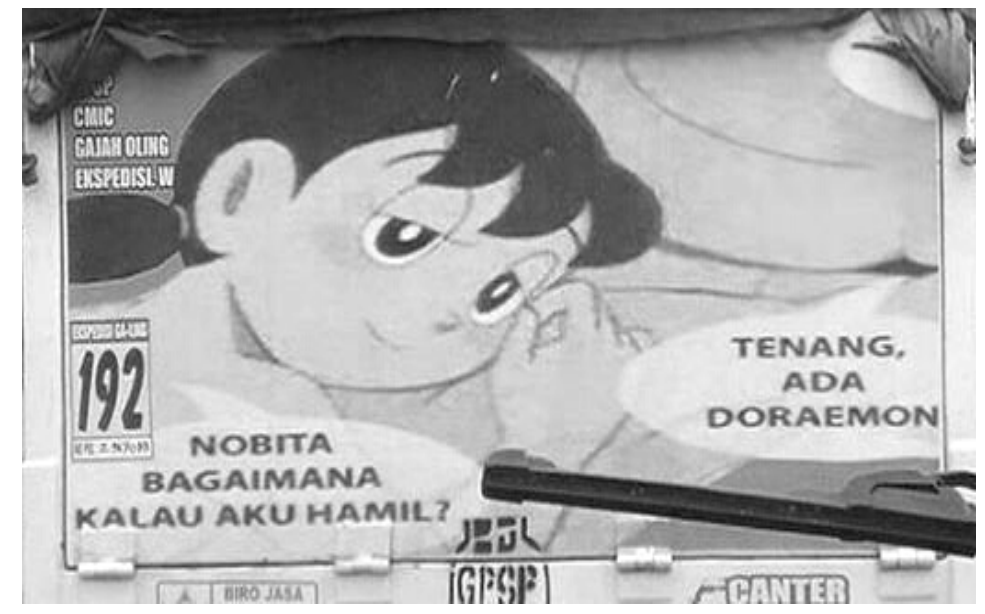

Gambar 11. Implikatur Doraemon

Untuk memahami implikatur, Wang (2011:1162) menjelaskan perlu adanya pemahaman makna dan maksud dari situasi khusus yang digambarkan dalam implikatur dengan melakukan penelaahan aspek di luar kebahasaan. Berdasarkan hal itu, pada gambar 9, implikaturnya adalah aku (lakilaki) melakukan hubungan seksual dengan pacar-mu (perempuan) sampai perempuan itu hamil. Enklitik -mu yang melekat pada kata pacar mengindikasikan bahwa laki-laki tersebut mengenal sosok pacar perempuan yang dihamilinya. Pada gambar 10, laki-laki tampak berdoa agar dilindungi dari godaan wanita, seperti cabe-cabean, para mantan, wanita penghibur, tante girang, janda muda, dan istri orang. Hal itu memposisikan perempuan sebagai pihak yang menggoda, sedangkan laki-laki adalah yang tergoda. Perempuan direpresentasikan sebagai subjek yang mengawali tindakan negatif lakilaki. Bahkan, disebutkan label perempuan tidak baik yang berkembang di masyarakat, mulai dari cabe-cabean hingga istri orang. Banyaknya jenis godaan wanita tersebut secara implisit menjelaskan bahwa perempuan adalah makhluk penggoda, sedangkan lakilaki adalah korban godaan tersebut.

Pada gambar 10, tokoh kartun Doraemon dimanfaatkan. Pada cerita aslinya, Nobita dan Shizuka adalah anak-anak tetapi pada gambar tersebut justru melakukan hubungan 
seksual. Shizuka cemas jika sampai hamil, tetapiNobita mengabaikannya karena semua masalah dapat terselesaikan dengan bantuan alat canggih Doraemon, mungkin saja alat yang bisa menghilangkan kehamilan atau alat/ obat antihamil. Implikaturnya adalah saat ini anak-anak dan remaja dapat melakukan halhal yang dilakukan orang dewasa, seperti hubungan suami istri. Secara implisit, anakanak digambarkan dapat melakukan hubungan seksual sampai hamil, tetapi hal itu bukanlah masalah yang besar karena semua dapat terselesaikan jika dilakukan dengan cara yang tepat dan cepat, misalnya dengan meminta bantuan orang lain untuk menutupi/menghilangkan kehamilan tersebut. Jika ditinjau lebih jauh, Doraemon merupakan simbol orang/profesi yang dapat menutupi/menghilangkankehamilan tersebut, misalnya pihak yang melakukan praktik aborsi. Representasi yang tampak adalah perempuan dan lakilaki yang masih anak-anak dan remaja pada zaman sekarang makin mengkhawatirkan karena dapat bertindak jauh untuk memenuhi hasrat seksualnya. Hal itu tampak pada beberapa kasus pernikahan anak yang terjadi di beberapa wilayah di Indonesia dengan alasan si perempuan telah hamil.

4. Diksi Konotatif

Diksi konotatifmerupakan pilihan kata yang bermaknatersirat. Data disajikansebagaiberikut. Kata yang dicetak tebaladalah diksi konotatif.

Tabel 3. Temuan Diksi Konotatif

\begin{tabular}{|l|l|}
\hline \multicolumn{1}{|c|}{ Data } & \multicolumn{1}{c|}{ Interpretasi } \\
\hline Pacar isi ulang. & $\begin{array}{l}\text { Pacar yang statusnya bergantung pada banyaknya uang yang } \\
\text { didapatkan. Jika uang habis, tidak lagi berstatus pacar. Untuk } \\
\text { berstatus pacar lagi, perlu memberikan sejumlah uang. }\end{array}$ \\
\hline $\begin{array}{l}\text { Jangan dinikahi bila } \\
\text { segel rusak }\end{array}$ & $\begin{array}{l}\text { Anjuran untuk tidak menikahi perempuan yang telah kehilangan } \\
\text { keperawanan. }\end{array}$ \\
\hline Sedia bibit bayi. & $\begin{array}{l}\text { Tawaran laki-laki yang bersedia melakukan hubungan seksual } \\
\text { dengan perempuan untuk mendapatkan bayi. }\end{array}$ \\
\hline $\begin{array}{l}\text { Janda semakin di } \\
\text { depan. }\end{array}$ & $\begin{array}{l}\text { Meskipun janda, tetap tampak menarik, menggoda, dan dilirik } \\
\text { laki-laki. }\end{array}$ \\
\hline $\begin{array}{l}\text { Lali rupane eling } \\
\text { rasane. }\end{array}$ & $\begin{array}{l}\text { Lupa dengan wajahnya, tetapi tetap teringat dengan yang } \\
\text { dirasakan (kenikmatan hubungan suami istri). }\end{array}$ \\
\hline $\begin{array}{l}\text { Ora } \text { usah dolanan } \\
\text { barang nylempit, } \\
\text { enak'e sak menit, } \\
\text { rekosone sundul } \\
\text { langit. }\end{array}$ & $\begin{array}{l}\text { Anjuran untuk tidak bermain-main dalam hubungan seksual } \\
\text { dengan perempuan karena kenikmatannya hanya sementara, } \\
\text { tetapi akibat negatifnya tidak terkira. Hubungan seksual yang } \\
\text { dimaksud adalah hubungan yang ilegal, seperti selingkuh atau } \\
\text { hubungan di luar nikah. }\end{array}$ \\
\hline $\begin{array}{l}\text { Ora nduweni wes tau } \\
\text { numpak'i }\end{array}$ & $\begin{array}{l}\text { Laki-laki yang tidak menikahi seorang perempuan, tetapi sudah } \\
\text { pernah melakukan hubungan suami istri dengan perempuan } \\
\text { tersebut. }\end{array}$ \\
\hline
\end{tabular}

Pada tabel tersebut, diksi konotatif yang digunakan berkaitan dengan hubungan seksual dan citra perempuan yang materialistis. Perempuan digambarkan secara negatif jika kehilangan keperawanan, tetapi hal itu tidak berlaku demikian bagi laki-laki. Di sisi lain, laki-laki menjadikan perempuan sebagai pihak yang tidak berkuasa atas dirinya. Bahkan, perempuan menjadi objek seksual laki, baik dalam hubungan sah suami istri maupun hubungan yang tidak sah. 
SIMPULAN

Posisi mengenai bagaimana representasi wanita dalam budaya, khususnya melalui media komunikasi visual (gambar dan tulisan dibelakang bak truk) masih belum berubah. Perempuan diposisikan sebagai objek yang lemah dan tidak berkuasa atas dirinya. Fenomena gambar tentang representasi perempuan dalam tulisan dan gambar di belakang bak truk terlihat bagaimana ideologi para supir truk dalammerepresentasikan perempuan. Hasil penelitian menunjukkan bahwa perempuan lebih banyak direpresentasikan dalam hal uang, cinta, dan seks secara negatif. Perempuan digambarkan mengambil keuntungan darilaki-laki dariuang dan cinta yang didapatkannya. Perempuan diposisikan sebagai pihak yang berinisiasi sekaligus sebagai pihak yang menerima hasrat seks dari laki-laki. Bahasa yang digunakan adalah bahasa Indonesia dan bahasa Jawa. Penggunaan bahasa Jawa memiliki nilai emosional kuat karena konten yang disampaikan menyangkut hal yang intim sekali. Bahasa seksis langsung (overt sexism) berwujud pameo, kalimat imperatif, frasa nomina, sarkasme, serta kata dalam bahasa Indonesia atau bahasa Jawa yang lafalnya ditulis dalam bahasa Inggris. Bahasa seksis tak langsung (covert sexism) berwujud presuposisi, implikatur, repetisi, dan diksi konotatif. 


\section{DAFTAR RUJUKAN}

Adams, L. S. 2008. A History of Western Art Fourth Edition. New York: McGraw-Hill Higher Education.

Ademilokun, Mohammed dan Olateju, Moji. 2015. A Multimodal Discourse Analysis of Some Visual Images in The Political Rally Discourse of 2011 Electioneering Campaigns in Southwestern Nigeria. International Journal of Society, Culture, and Language Vol. 4(1):1-19.

Aitchison, J. 1994. "Say it again, Sam”. Fischer, A. (Ed.). Swiss Papers in English Language and Literature 7 Repetition. Tuebingen: Gunter Narr Verlag.

Astuti, Santi Indra. 2004. Representasi Perempuan Indonesia dalam Komunikasi Visual: Wacana yang (Belum) Berubah. Jurnal Mediator Vol. 5 No. 2

Becker, Julia C.; Zawadzki, Matthew J.; dan Shields, Stephanie A. 2014. Confronting and Reducing Sexism: A Call for Research on Intervention. Journal of Social Issues Vol. 70 (4):603-614.

Cameron. D. 2006. Language and Social Politics. London: Routledge.

Christandi, DB. 2013. Representasi Perempuan dalam Film Sang Penari: Kajian Semiotika Roland Barthes. Skripsi. Salatiga: Fakultas Ilmu Sosial dan Komunikasi Universitas Kristen Satya Wacana.

Connolly, J., \& Phillips, I. 2002. Semiotics and The Theoretical Foundations of Multimedia. Semiotica, 144(1/4), 169-184.

Darwesh, Abbas Degan dam Abdullah, Nesaem Mehdi. 2016. ACritical Discourse Analysis of Donald Trump's Sexist Ideology. Journal of Education and Practice Vol. 7 (30): 87-95.
Fairclough, Norman. 2016. ADialectical-RelationalApproach to Critical Discourse Analysis is Social Research. Wodak, Ruth dan Meyer, Michael (Eds.). Methods of Critical Discourse Studies Third Edition. London: SAGE Publication Ltd.

Fakih, Mansour. 1996. Analisa Gender dan Tranformasi Sosial. Yogyakarta: Pustaka Pelajar.

Jancsary, Dennis; Hollerer, Markus A.; dan Meyer, Renate A. 2016. Critical Analysis of Visual and Multimodal Texts. Wodak, Ruth dan Meyer, Michael (Eds.). Methods of Critical Discourse Studies Third Edition. London: SAGE Publication Ltd.

Juwita, Norma. 2009. Penggunaan Kosa Kata Oleh Laki-Laki dan Perempuan Dalam Wacana Deskriptif. Skirpsi. Jakarta: Fakultas Ilmu Budaya Universitas Indonesia.

Knox, John S.; Patpong, Pattama; dan Piriyasilpa, Yupaporn. 2010. Khao Naa Nung: A Multimodal Analysis of Thai-language Newspaper Front Pages. Bednarek, Monika dan Martin, J.R. Martin (Eds.). New Discourse on Language: Functional Perspectives on Multimodality, Identity, and Affiliation. London/New York: Continuum International Publishing Group.

Kurnia, Novi. 2004. Representasi Maskulinitas dalam Iklan. Jurnal Ilmu Sosial dan Politik. Vol. 8 No 1.

Mautner, Gerlinde. 2016. Checks and Balances: How Corpus Linguistics can Contribute to CDA. Wodak, Ruth dan Meyer, Michael (Eds.). Methods of Critical Discourse Studies Third Edition. London: SAGE Publication Ltd. Mills, S. 2008. Language and Sexism. Cambridge: Cambridge University Press.

Moleong, L.J. 2014. Metodologi Penelitian Kualitatif. Bandung: Remaja Rosda Karya. 
Mondong, Tony. 2011. Representasi Perempuan dalam Iklan Pond's. Jurnal Inovasi Vol. 8 No.1.

Peccei, J.S. 2000. Pragmatics. London and New York: Routledge

Ponterotto, Diane. 2014. Trivializing the Female Body: ACross-cultural Analysis of the Representation of Women in Sports Journalism. Journal of International Women's Studies, 15(2), 94-111.

Ponulele, Nurhayati dkk. 1998. Ungkapan dan Peribahasa Bahasa Kaili. Jakarta: Pusat Pembinaan dan Pengembangan Bahasa Departemen Pendidikan dan Kebudayaan.

Sneddon, J. N. dkk. 2010. Indonesian: $A$ Reference Grammar $2^{\text {nd }}$ Edition. Sydney: Allen \& Unwin.

Suharsaputra, U. 2012. Metode Penelitian: Kuantitatif, Kualitatif, dan Tindakan. Bandung: Refika Aditama.

Swim, J. K., dan Hyers, L. L. 2009. Sexism. Nelson, T. D. (Ed.). Handbook of Prejudice,
Stereotyping, and Discrimination. New York: Psychology Press.

Tian, Ping. 2010. Playing with 'Feminity': An Intermodal Analysis of The Bilingual Picture Book The Ballad of Mulan. Bednarek, Monika dan Martin, J.R. Martin(Eds.). New Discourse on Language: Functional Perspectives on Multimodality, Identity, and Affiliation. London/New York: Continuum International Publishing Group.

Vahid, Hossein dan Esmae'li, Saeedeh. 2012. The Power behind Images: Advertisement Discourse in Focus. International Journal of Linguistics Vol. 4 (4): 36-51.

Wang, Haiyan. 2011. Conversational Implicature in English Listening Comprehension. Journal of Language Teaching and Research Vol. $2(5)$ : 1162-1167.

Widjaja, HAW. 1997. Komunikasi dan Hubungan Masyarakat. Jakarta: BumiAksara

Zed, Mestika. 2008. Metode Penelitian Kepustakaan. Jakarta: Yayasan Obor Indonesia. 